\title{
Pengaruh Substitusi Bungkil Kedelai dengan Daun Kelor (M. oleifera) terhadap Profil Darah Merah Kambing Pra -Sapih
}

\author{
The Effect of Soybean Meal Substitution with Kelor Leaf (M. oleifera) on Erythrocyte Profiles \\ in Pre - Weaning Goats
}

\author{
A. N. Rohmah, F. Wahyono, dan J. Achmadi \\ Fakultas Peternakan dan Pertanian Universitas Diponegoro \\ Tembalang 50275, Semarang, Indonesia \\ Corresponding Author: Alfiananurrohmah@gmail.com
}

\begin{abstract}
The purpose of this study was to determine the effect of Moringa oleifera leaf on the number of erythrocyte, hemoglobin, and hematocrits in pre weaning goats. The experiments used 12 female Jawarandu goats kids, aged at 2 - 3 month old with body weight averageof $9.21 \pm 1.43 \mathrm{~kg}$. Soybean meal protein was replaced with Moringa leaf protein in starter feed. A complete random design was used in this study with 3 treatments and 4 replicates, those were T0 ( $100 \%$ soybean meal protein), T1 (75\% soybean meal protein $+25 \%$ Moringa leaf protein), and T2 $(25 \%$ soybean meal protein $+75 \%$ Moringa leaf protein). All dietsary treatments were designed to have \pm $20 \% \mathrm{CP}$ (crude protein) and $\pm 70 \% \mathrm{TDN}$ (total digestible nutrient). Data were analized using ANOVA and continued with Duncan's multiple range test when any significant effect was found. There was no significant different $(\mathrm{P}>0.05)$ among treatments for dry matter consumption, weight gain, and blood total erythrocyte, percentage hemoglobin, and hamatocrit. It could be concluded that the M. oleifera leaf protein may substitute soybean meal protein up to $75 \%$ in ration.
\end{abstract}

Key words : M. oleifera leaf, pre weaning goats, erythrocyte, hemoglobin, hematocrite

\begin{abstract}
ABSTRAK
Penelitian ini bertujuan untuk mengetahui pengaruh pemberian tepung daun kelor ( $M$. oleifera) terhadap total eritrosit, kadar hemoglobin, dan nilai hematokrit pada kambing pra sapih. Materi yang digunakan adalah 12

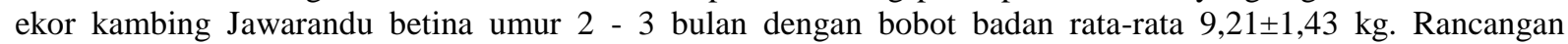
percobaan yang digunakan adalah rancangan acak lengkap dengan 3 perlakuan dan 4 ulangan. Pakan perlakuan yang diberikan yaitu T0 (100\% protein bungkil kedelai), T1 (75\% protein bungkil kedelai $+25 \%$ protein tepung daun kelor), dan T2 (75\% protein bungkil kedelai $+25 \%$ protein tepung daun kelor). Ketiga ransum mempunyai kandungan $\mathrm{PK} \pm 20 \%$ dan TDN $\pm 70 \%$. Data dianalisis dengan ANOVA apabila terdapat perbedaan dilanjutkan dengan uji jarak berganda Duncan. Hasil penelitian menunjukkan bahwa pemberian tepung daun kelor tidak berpengaruh nyata $(\mathrm{P}>0,05)$ terhadap konsumsi bahan kering, pertumbuhan bobot badan, total eritrosit, kadar hemoglobin, dan nilai hematokrit. Sebagai kesimpulan daun kelor dapat menggantikan protein bungkil kedelai sampai pada taraf $75 \%$ dalam ransum.
\end{abstract}

Kata kunci: Tepung daun kelor, kambing pra sapih, eritrosit, hemoglobin, hematokrit

\section{PENDAHULUAN}

Kambing Jawarandu merupakan ternak penghasil daging yang mempunyai pertumbuhan cepat dan mampu beradaptasi dengan baik di Indonesia. Kambing biasanya disapih pada umur tiga bulan, semakin cepat penyapihan maka semakin baik karena induk kambing bisa cepat kawin dan bunting lagi. Kambing pra sapih membutuhkan pakan dengan kandungan protein tinggi karena rumennya belum berkembang dengan sempurna. Sumber protein yang sering digunakan dalam pakan adalah bungkil kedelai. Ketersediaan bungkil kedelai di Indonesia masih tergantung pada impor, hal ini menyebabkan harga bungkil kedelai melambung tinggi. Daun kelor (Moringa oleifera) merupakan tanaman yang berpotensi sebagai bahan pakan pengganti bungkil kedelai. Jayanegara et al. (2010) menyatakan bahwa daun kelor mempunyai kandungan protein sebesar $27 \%$ sehingga berpotensi sebagai bahan pakan sumber protein. 
Tanaman kelor dapat tumbuh dengan baik di daerah tropis seperti di Indonesia dan daun kelor dapat dipanen sepanjang tahun tidak bergantung pada musim. Selain mempunyai kandungan protein yang tinggi, daun kelor mengandung senyawa antioksidan (fenolinik dan flavonoid) yang dapat mengurangi stres oksidatif. Kelemahan daun kelor adalah mempunyai zat antinutrisi berupa tannin dan saponin yang apabila jumlahnya berlebih dapat berpengaruh negatif terhadap kesehatan tubuh ternak.

Senyawa antinutrisi yang terkandung dalam pakan dapat mempengaruhi sel darah merah (total eritrosit, hemoglobin, dan nilai hematokrit). Saponin dapat merusak sel darah merah karena mampu berikatan dengan kolesterol dan menurunkan tegangan sel membran (Wina, 2012), sedangkan tannin mengganggu penyerapan zat besi $(\mathrm{Fe})$ dan dapat mengikat protein dan mineral sehingga sukar dicerna oleh tubuh (Fajrina et al., 2007). Pembentukan sel darah merah membutuhkan suplai nutrisi berupa protein dan mineral. Kambing yang kekurangan protein dan zat besi akan mengalami kekurangan sel darah merah.

Rumen pada kambing pra sapih belum berkembang dengan sempurna, sehingga tidak dapat mencerna pakan secara fermentatif. Proses pencernaan yang menyerupai hewan monogastrik menyebabkan kambing pra sapih sangat peka terhadap kandungan antinutrisi dalam pakan.
Penggunaan tepung daun kelor pada teraf tertentu sebagai pengganti bungkil kedelai diharapkan tidak memberikan pengaruh negatif terhadap profil darah merah kambing pra sapih.

Penelitian ini bertujuan untuk mengetahui pengaruh pemberian tepung daun kelor terhadap total eritrosit, kadar hemoglobin, dan nilai hematokrit pada kambing jawarandu pra sapih. Manfaat penelitian ini adalah memberikan informasi kepada masyarakat mengenai penggunaan daun kelor sebagai pakan kambing pra sapih. Hipotesis penelitian ini yaitu tepung daun kelor pada taraf tertentu dapat menggantikan bungkil kedelai sebagai bahan pakan sumber protein tanpa menurunkan profil darah merah pada kambing Jawarandu pra sapih.

\section{MATERI DAN METODE}

Tabel 1 merupakan formulasi ransum yang digunakan untuk pakan kambing perlakuan. Materi penelitian yang digunakan adalah 12 ekor kambing Jawarandu betina umur 2 - 3 bulan dengan bobot badan ratarata 9,21 $\pm 1,43 \mathrm{~kg}$. Daun kelor dikumpulkan dari daerah Gunungpati, Kota Semarang dan Ungaran, Kabupaten Semarang. Daun kelor yang telah terkumpul dikeringkan dibawah sinar matahari kemudian dihaluskan menggunakan grinder. Alat yang digunakan untuk menganalisis sampel darah adalah alat hematology analyzer beserta reagennya.

Tabel 1. Komposisi bahan pakan dan kandungan nutrien ransum

\begin{tabular}{lccc}
\hline \multirow{2}{*}{ Bahan Pakan } & \multicolumn{3}{c}{ Jumlah $(\%)$} \\
& T0 & T1 & T2 \\
\cline { 2 - 4 } Onggok & 18.5 & 5,00 & 1,00 \\
Molases & 2,00 & 2,00 & 2,00 \\
Jagung kuning & 14,0 & 32,0 & 36,0 \\
Bungkil kedelai & 45,0 & 33,75 & 11,3 \\
Tepung daun kelor & - & 15,56 & 46,7 \\
Dedak padi & 18,5 & 10,00 & 1,00 \\
Mineral & 2,00 & 2,00 & 2,00 \\
\hline Total & 100,00 & 100,00 & 100,00 \\
\hline PK & 20,24 & 20,16 & 19,60 \\
TDN & 75,48 & 75,06 & 71,22 \\
\hline
\end{tabular}

Setiap ransum mempunyai komposisi bahan pakan yangsama tetapi peresentase setiap bahan pakan dalam ransum berbedabeda tergantung pada jenis perlakuan. 
Bungkil kedelai disubstitusi dengan tepung daun kelor berdasarkan proteinnya. Sumber protein pakan perlakuan dapat dilihat pada Tabel 2. Setiap ransum mempunyai kandungan nutrien yang hampir sama yaitu $\mathrm{PK} \pm 20 \%$ dan $\mathrm{TDN} \pm 70 \%$. Pakan diberikan selama 4 minggu dimulai dari berakhirnya masa adaptasi. Selama perlakuan kambing pra sapih diberi pakan selama dua kali sehari pagi dan sore.

Tabel 2. Sumber protein pakan

\begin{tabular}{|c|c|c|c|}
\hline \multirow[b]{2}{*}{ Pakan } & \multirow[b]{2}{*}{$\mathrm{PK}(\%)$} & \multicolumn{2}{|c|}{ Sumber Protein $(\%)$} \\
\hline & & $\begin{array}{l}\text { Bungkil } \\
\text { kedelai }\end{array}$ & $\begin{array}{c}\text { T. daun } \\
\text { kelor }\end{array}$ \\
\hline T0 & 20,24 & 100 & 0 \\
\hline $\mathrm{T} 1$ & 20,16 & 75 & 25 \\
\hline $\mathrm{T} 2$ & 19,60 & 25 & 75 \\
\hline
\end{tabular}

\section{Pengambilan Data}

Selama penelitian berlangsung, dilakukan pengambilan data performans kambing pra sapih meliputi konsumsi ransum dan pertambahan bobot badan. Konsumsi ransum setiap hari diukur dengan menghitung selisih pemberian dan sisa ransum. Pertambahan bobot badan harian dihitung dengan mengurangi bobot akhir dengan bobot awal sebelum perlakuan kemudian dibagi 28 hari. Pengambilan darah dilakukan setelah 28 hari pemeliharaan. Darah diambil melalui vena jugularis pada leher kambing menggunakan spuit ukuran 5 ml. Darah dimasukkan ke dalam tabung EDTA vacutainer dan disimpan dalam cool box berisi es batu. Sampel darah digunakan untuk pengukuran jumlah eritrosit, kadar hemoglobin, dan nilai hematokrit darah.

\section{Analisis Sampel Darah}

Jumlah eritrosit, kadar hemoglobin, dan nilai hematokrit diukur menggunakan alat hematology analyzer (Anjue Medical Equipment, China). Pengukuran eritrosit dan hematokrit dilakukan dengan metode elektroda impedance, hemoglobin diukur dengan metode spektofotometri. Metode analisis darah menggunakan alat hematology analyzer yaitu tabung EDTA vacutainer yang berisi darah didekatkan pada jarum penghisap sampel. Tombol penghisap sampel ditekan, selanjutnya alat akan secara otomatis menganalisa darah. Hasil pengukuran akan tampak pada kertas print out.

\section{Rancangan Percobaan}

Rancangan percobaan yang digunakan adalah rancangan acak lengkap yang terdiri dari 3 perlakuan dan 4 ulangan. erlakuan yang diterapkan adalah :

$\mathrm{T}_{0}=$ Ransum dengan $100 \%$ protein bungkil kedelai

$\mathrm{T}_{1}=$ Ransum dengan $75 \%$ protein bungkil kedelai $+25 \%$ protein daun kelor

$\mathrm{T}_{2}=$ Ransum dengan $25 \%$ protein bungkil kedelai $+75 \%$ protein daun kelor

Data yang diperoleh diolah dengan analisis ragam uji $\mathrm{F}$ pada taraf signifikasi 5 $\%$, apabila terdapat perbedaan dilanjutkan dengan uji jarak berganda Duncan.

\section{HASIL DAN PEMBAHASAN}

Berdasarkan Tabel 3. dibawah ini menunjukkan hasil penelitian mengenai pengaruh substitusi bungkil kedelai dengan daun kelor $(M$. oleifera) terhadap profil darah merah kambing pra sapih.

Tabel 3. Konsumsi bahan kering, pertambahan bobot badan, jumlah eritrosit, kadar hemoglobin, dan kadar hematokrit kambing Jawarandu pra sapih

\begin{tabular}{lcccc}
\hline Parameter & T0 & T1 & T2 & SEM \\
\hline Konsumsi bahan kering (g/hari) & 274,69 & 260,98 & 306.24 & 11,93 \\
Total eritrosit $\left(\mathrm{x} 10^{6} / \mu \mathrm{l}\right)$ & 1,44 & 1,64 & 1,91 & 0,20 \\
Kadar hemoglobin $(\mathrm{g} / \mathrm{dl})$ & 6,13 & 6,50 & 7,00 & 0,17 \\
Nilai hematokrit $(\%)$ & 25,25 & 30,00 & 30,75 & 1,34 \\
Pertambahan bobot badan $(\mathrm{g} /$ hari) & 42,52 & 50,09 & 66,70 & 4.56 \\
\hline
\end{tabular}

Keterangan : SEM : pooled standard error of means 


\section{Konsumsi Bahan Kering}

Tabel 3. menunjukkan bahwa substitusi bungkil kedelai dengan tepung daun kelor dalam ransum tidak berpengaruh nyata $(\mathrm{P}>0,05)$ terhadap konsumsi bahan kering kambing jawarandu pra sapih. Hal ini menunjukkan bahwaselera kambing jawarandu pra sapih tetap sama meskipun tepung daun kelor mempunyai bau dan rasa berbeda dengan bungkil kedelai. Anggorodi (1994) menyatakan bahwa sifat fisik yaitu bentuk, aroma, rasa, dan tekstur bahan pakan akan mempengaruhi palatabilitas pakan. Suparman et al. (2016) menambahkan bahwa salah satu faktor yang mempengaruhi konsumsi ransum kambing adalah palatabilitas jenis bahan pakan yang diberikan. Perbedaan bentuk dan jenis bahan pakan dalam ransum menyebabkan perbedaan jumlah pakan yang dikonsumsi oleh ternak. Tepung daun kelor mempunyai palatabilitas yang sama dengan bungkil kedelai sehingga substitusi bungkil kedelai dengan tepung daun kelor tidak mempengaruhi konsumsi pakan.

Zat antinutrisi tannin dan saponin yang terkandung dalam tepung daun kelor tidak mempengaruhi konsumsi bahan kering kambing jawarandu pra sapih. Suharti (2009) menyatakan bahwa pemberian saponin pada level 2,5 \% dalam pakan sapi dapat menurunkan palatabilitas karena rasanya yang pahit. Pemberian protein daun kelor sampai pada taraf $75 \%$ tidak mempengaruhi konsumsi pakan kambing Jawarandu pra sapih karena kambing masih dapat mentolerir rasa pahit. Hal ini sesuai dengan pendapat Devandra dan Burn (1994) yang menyatakan bahwa kambing mempunyai toleransi yang lebih tinggi terhadap rasa pahit dibandingkan dengan sapi.

\section{Total Eritrosit}

Rataan total eritrosit digambarkan dalam diagram batang pada Gambar 1. Tabel 3. menunjukkan bahwa substitusi protein bungkil kedelai dengan protein tepung daun kelor dalam ransum tidak berpengaruh nyata $(\mathrm{P}>0,05)$ terhadap total eritrosit kambing Jawarandu pra sapih. Konsumsi bahan kering dan kandungan protein ransum pada semua perlakuan adalah sama sehingga protein yang dikonsumsi tidak berbeda. Hoffbrand dan Pettit (1996) menyatakan bahwa setiap hari pembentukan eritrosit baru membutuhkan prekusor berupa zat besi, vitamin, asam amino, dan hormon. Yatno (2011) menyatakan bahwa bungkil kedelai mempunyai kandungan asam amino berupa asparagin, glutamat, serin, glisinin, arginin, alanin, tirosin, histidin, treonin, metionin, valin, fenilalanin, isoleusin, leusin, dan lisin. Aminah et al. (2015) menyatakan bahwa daun kelor kering mengandung asam amino berupa arginin, histidin, isoleusin, lisin, metionin, fenilalanin, treonin, tryptophan, dan valin. Kandungan asam amino bungkil kedelai lebih lengkap dibandingkan dengan tepung daun kelor tetapi terbukti tidak mempengaruhi total eritrosit. Hal ini menunjukkan bahwa asam amino yang terkandung dalam tepung daun kelor dapat menggantikan asam amino bungkil kedelai sehingga pembentukan sel darah merah tidak terganggu.

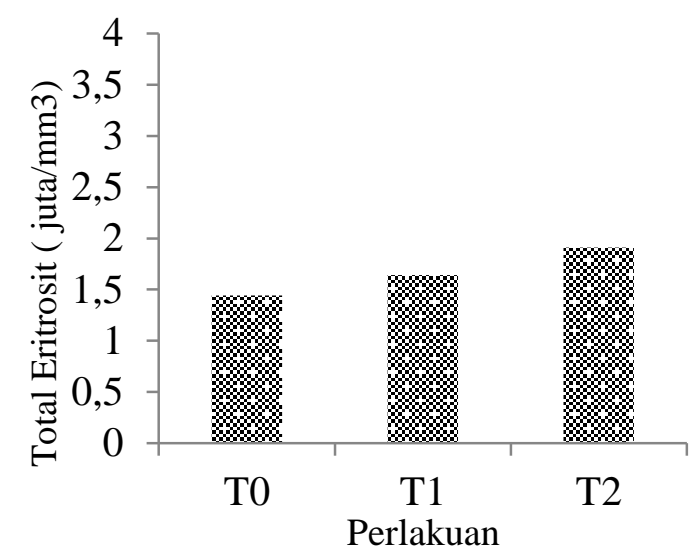

Gambar 1. Rataan total eritrosit kambing Jawarandu pra sapih

Pemberian protein daun kelor sampai pada taraf $75 \%$ tidak mempengaruhi total eritrosit meskipun daun kelor mempunyai senyawa antinutrisi tannin dan saponin yang dalam jumlah berlebih dapat mempengaruhi total eritrosit pada tubuh ternak. Fajrina et al. (2007) meyatakan bahwa tanin mengganggu penyerapan zat besi $(\mathrm{Fe})$ dan dapat mengikat protein dan mineral sehingga sukar dicerna oleh tubuh. Saponin dapat merusak sel darah merah karena berikatan dengan kolesterol 
dan menurunkan tegangan sel membran (Wina, 2012). Teixeira et al. (2014) menyebutkan bahwa daun kelor yang dikeringkan mengandung 13,2 - 20,6 g tannin/kg. Jumlah saponin dalam daun kelor adalah sebesar 4,91 \% dari bahan kering (Musmulyadi, 2011). Zat antinutrisi tannin dan saponin dalam daun kelor terbukti tidak mempengaruhi total eritrosit karena konsumsi tannin dan saponin masih dapat ditolerir oleh kambing Jawarandu pra sapih. Preston dan Leng (1987) menyatakan bahwa kadar tannin yang masih dapat ditoleransi oleh tubuh ternak ruminansia adalah sebesar 2 - $4 \%$ dari bahan kering. Musmulyadi (2011) menyebutkan bahwa konsumsi saponin sebesar 11,64 - 20,56 g/ekor/hari tidak mempengaruhi eritrosit domba. Tepung daun kelor dibuat dengan cara dijemur di bawah sinar matahari sampai kering sehingga kandungan zat anti nutrisinya dapat berkurang. Rachmawati et al. (2006) menyatakan bahwa pengeringan dibawah sinar matahari dapat menurunkan kadar saponin karena adanya reaksi hidrolisis dan oksidasi (fotodegradasi).

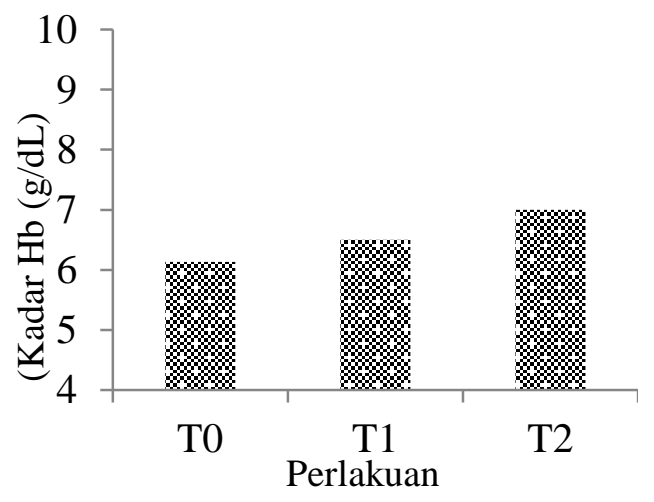

Gambar 2. Kadar Hemoglobin Kambing Jawarandu Pra Sapih

\section{Kadar Hemoglobin}

Rataan kadar hemoglobin digambarkan dalam diagram batang pada Gambar 2. Tabel 3. menunjukkan bahwa substitusi protein bungkil kedelai dengan protein tepung daun kelor dalam ransum tidak berpengaruh nyata $(\mathrm{P}>0,05)$ terhadap kadar hemoglobin kambing Jawarandu pra sapih. Kadar hemoglobin setiap perlakuan tidak berbeda karena semua kambing perlakuan mempunyai aktivitas fisik yang sama sehingga asupan oksigen yang masuk ke paru-paru jumlahnya sama. Hemoglobin merupakan bagian dari sel darah merah yang mengikat oksigen. Kadar hemoglobin dipengaruhi oleh kebutuhan oksigen dalam tubuh. Semakin besar oksigen maka semakin besar kadar hemoglobin. Hal ini sesuai dengan pendapat Alfian et al. (2017) yang menyatakan bahwa hemoglobin dipengaruhi oleh kadar oksigen sehingga apabila oksigen dalam darah tinggi maka tubuh akan terangsang untuk memproduksi hemoglobin. Adriyanto (2010) menyatakan bahwa kebutuhan oksigen dipengaruhi oleh peningkatan denyut jantung dan aliran darah ke otot. Semakin banyak aktivitas tubuh ternak maka denyut jantung dan metabolisme meningkat sehingga tubuh membutuhkan oksigen lebih banyak.

Hemoglobin pada ketiga perlakuan yang tidak berbeda juga dapat disebabkan karena total eritrosit dari ketiga perlakuan sama. Kadar hemoglobin berhubungan erat dengan total eritrosit darah. Frandson (1996) menyatakan bahwa hemoglobin merupakan bagian dari eritrosit yang dapat mengikat oksigen untuk peletdarkan ke seluruh jaringan tubuh. Musmulyadi (2011) menyatakan bahwa hemoglobin berfungsi sebagai pengangkut oksigen dari paru-paru ke seluruh jaringan tubuh serta merupakan pigmen dalam eritrosit. Satu molekul hemoglobin dapat mengikat empat molekul oksigen. Kadar hemoglobin pada ternak selain dipengaruhi oleh aktivitas fisik juga dipengaruhi oleh jenis kelamin, umur, bangsa, status nutrisi, kondisi fisiologis, dan keadaan lingkungan kandang.

\section{Nilai Hematokrit}

Rataan nilai hematokrit digambarkan dalam diagram batang pada Gambar 3.Tabel 3. menunjukkan bahwa substitusi protein bungkil kedelai dengan protein tepung daun kelor dalam ransum tidak berpengaruh nyata $(\mathrm{P}>0,05)$ terhadap kadar hematokrit kambing jawarandu pra sapih. Hal ini dapat terjadi karena total eritrosit dan kadar hemoglobin 
pada ketiga perlakuan tidak berbeda. Hematokrit merupakan perbandingan eritrosit dengan darah sehingga nilainya berkorelasi positif dengan total eritrosit. Hal ini sesuai dengan pendapat. Guyton dan Hall (1997) yang menyatakan bahwa hematokrit atau biasa disebut dengan PCV (Packed Cell Volume) merupakan presentase dari total sel darah merah dari seluruh volume darah. Semakin tinggi persentase sel darah merah dan hemoglobin maka akan semakin tinggi nilai hematokrit.

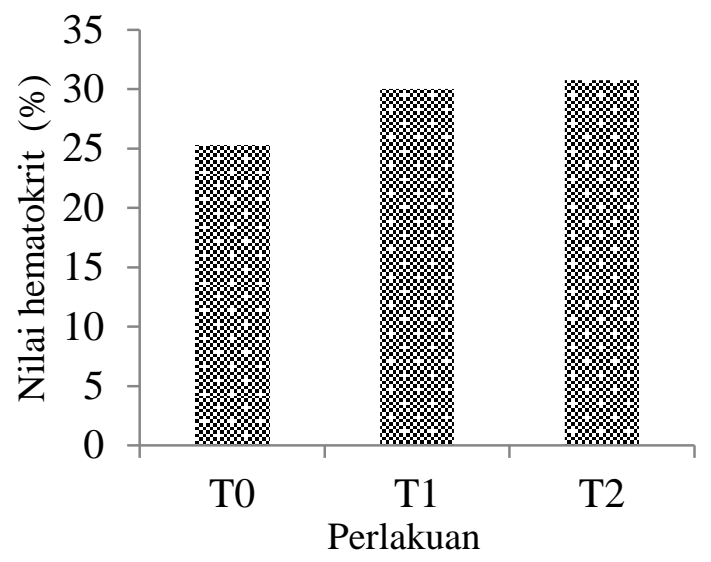

Gambar 3. Nilai Hematokrit Kambing Jawarandu Pra Sapih

Kadar hematokrit kambing jawarandu pra sapih pada semua perlakuan menunjukkan hasil yang tidak berbeda dengan penelitian Yanti (2013) yang menyebutkan bahwa nilai hematokrit kambing PE dara adalah sebesar 22,6 - 31,15 $\%$. Kambing yang mempunyai kadar hematokrit normal menandakan bahwa kambing dalam keadaan sehat. Isroli et al. (2009) menjelaskan bahwa jika kadar hematokrit pada ternak rendah menandakan ternak tersebut dalam keadaan sakit. Kadar hematokrit yang terlalu tinggi justru berbahaya bagi tubuh. Cunningham (2002) menyatakan bahwa meningkatnya nilai hemtokrit dapat menaikkan viskositas (kekentalan) darah dan menyebabkan perlambatan aliran darah pada kapiler sehingga meningkatkan kerja jantung.

\section{Pertambahan Bobot Badan}

Tabel 3 menunjukkan bahwa substitusi protein bungkil kedelai dengan protein tepung daun kelor dalam ransum tidak berpengaruh nyata $(\mathrm{P}>0,05)$ terhadap pertumbuhan bobot badan harian kambing jawarandu pra sapih. Hal ini dapat disebabkan karena konsumsi bahan kering tidak berbeda dan kandungan nutrien ketiga pakan perlakuan sama. Konsumsi bahan kering sama menyebabkan protein dan energi yang dikonsumsi kambing juga sama. Alim (2014) menyatakan bahwa pertumbuhan ternak berhubungan erat dengan energi dan protein. Ternak yang diberi pakan dengan kandungan protein dan energi lebih dari untuk hidup pokok, akan memanfaatkan kelebihan nutrien untuk pertumbuhan jaringan tubuh.

Parakkasi (1995) menyatakan bahwa protein merupakan makro nutrien yang dibutuhkan ternak untuk pertumbuhan jaringan yang berakibat pada meningkatnya bobot badan. Kambing fase pra sapih membutuhkan asupan protein untuk fokus pada pembentukan jaringan tubuh. Fungsi darah berkaitan erat dengan pembentukan jaringan tubuh. Hal ini sesuai dengan pendapat Patria (2013) yang menyatakan bahwa darah berfungsi membawa nutrien yang telah diabsorbsi oleh saluran pencernaan ke seluruh jaringan tubuh. Pembentukan protein jaringan tubuh kambing pra sapih hanya mengandalkan suplai asam amino yang dibawa oleh darah. Asam amino yang diserap oleh usus halus peletdarkan oleh darah menuju ke seluruh tubuh untuk pembentukan jaringan. Konsumsi protein dan profil darah yang tidak berbeda nyata menyebabkan asam amino yang didistribusikan dan dideposisikan menjadi protein jaringan jumlahnya sama sehingga menghasilkan pertambahan bobot badan yang sama.

\section{KESIMPULAN}

Hasil penelitian menunjukkan bahwa protein tepung daun kelor mampu menggantikan protein bungkil kedelai sampai pada taraf $75 \%$ karena tidak mempengaruhi konsumsi bahan kering, pertambahan bobot badan, dan profil darah merah (total eritrosit, kadar hemoglobin, dan kadar hematokrit) 
kambing Jawarandu pra sapih. Pemberian protein tepung daun kelor sampai pada taraf $75 \%$ terbukti tidak mempengaruhi profil darah merah sehingga aman untuk dikonsumsi kambing pra sapih. Penelitian lebih lanjut mengenai pemberian protein tepung daun kelor sampai pada taraf $100 \%$ perlu dilakukan, semakin besar penggunaan tepung daun kelor akan semakin baik karena mengurangi ketergantungan pemakaian bungkil kedelai.

\section{DAFTAR PUSTAKA}

Adriyanto, Rahmadani, Y. Setyaningtijas, dan A. Sutisna. 2010. Gambaran hematologi domba selama transportasi: peran multivitamin dan mineral. Jurnal Ilmu Pertanian Indonesia 15 (3):172-177.

Alfian, Dasrul, dan Azhar. 2017. Jumlah eritrosit, kadar hemoglobin, dan nilai hematokrit pada ayam Bangkok, ayam kampung, dan ayam peranakan. JIMVET 1 (3): 533 539.

Alim, H. 2014. Pertambahan Bobot Badan Kambing Marica Jantan dengan Pemberian Pakan Komplit pada Taraf Protein yang Berbeda. Fakultas Peternakan Universitas Hasanuddin, Makassar. (Skripsi Sarjana Peternakan).

Aminah, S., R. Tezar, dan Y. Mulihani. 2015. Kandungan nutrisi dan sifat fungsional tanaman kelor (Moringa oleifera). Buletin Pertanian Perkotaan 5 (2): 35-44.

Anggorodi, R. 1994. Ilmu Makanan Ternak. Gramedia Pustaka Utama, Jakarta.

Cunningham, J. G. 2002. Textbook of Veterinary Phisiology. Saunders Company, USA.

Devendra, C. and M. Burns. 1993. Goat Production in the Tropics. Commonwealth Bureaux, London p 6474, 90-116.

Fajrina, A. Junuarty, dan S. Stevani. 2016. Penetapan kadar tanin pada teh celup yang beredar dipasaran secara spektrofotometri uv-vis. Jurnal Farmasi Higea 8 (2): 133-142.
Frandson, R. D., W. L. Wike and A. D. Fails. 2009. Anatomy and Physiology of Farm Animals. 7th Ed. Wiley-Blackell, Ames, Lowa.

Guyton, H. 1997. Buku Ajar Fisiologi Kedokteran. EGC, Jakarta. (Diterjemahkan oleh I. Setiawan).

Hoffbrand, A. V. dan J. E. Pettit. 1996. Kapita selekta: Hematologi (Essential Haemotology) Edisi 2. Buku Kedokteran EGC, Jakarta.

Isroli, E. Widiastuti, S. Susanti, T. Yudiharti dan Sugiharto. 2009. Observasi beberapa variable hematologi ayam Kedu pada pemeliharaan intensif. Prosiding Seminar Nasional Kebangkitan Peternakan. Hal: 548-557.

Jayanegara, A., T. Sabhan, A. K. Takyi, A. O. Salih and E. M. Hoffmann. 2010. Ruminal fermentation kinetics of Moringa and Peltiphyllum Supplements during early incubation period in the in vitro. Reading pressure technique. J. Indonesian Trop. Anim. Agric., 35 (3): 165-171.

Musmulyadi. 2011. Profil darah dan konsentrasi serum protein pada domba yang diberi daun Moringa oleifera lamk, Gliricidia sepium dan Artocarpus heterophyllu. Fakultas Peternakan Institut Pertanian Bogor, Bogor (Skripsi Sarjana Peternakan).

Ogbe, A. O. and J. P. Affiku. 2012. Effect of polyherbal aqueous extract (Moringa oleifera) Arabic gum, and wild Ganoderma lucidum) in comparison withantibiotic on growth performance and haematological parameters of broilerschickens. Res. J. Recent Sci 1(7):10-18.

Parakkasi, A. 1995. Ilmu Makanan dan Ternak Ruminan. Universitas Indonesia Press, Jakarta.

Patria, D. Praseno, K. dan Tana, S. 2013. Kadar hemoglobin dan jumlah eritrosit puyuh (Cotunix coturnix japonica Linn.) setelah pemberian larutan kombinasi 
mikromineral $(\mathrm{Cu}, \mathrm{Fe}, \mathrm{Zn}, \mathrm{Co})$ dan vitamin $(\mathrm{A}$, $\left.\mathrm{B}_{1} \mathrm{~B}_{12}, \mathrm{C}\right)$ dalam air minum. Buletin Animal dan Fisiologi 21 (1): 26-35.

Praseno, K. 2005. Respon eritrosit terhadap perlakuan mikromineral $\mathrm{Cu}, \mathrm{Fe}$, dan $\mathrm{Zn}$ pada Ayam (Gallus gallus domesticus). J. Ind. Trop. Anim. Agric. 30 (3): 179-185.

Preston, T. R. dan R. A. Leng. 1987. Matcing Ruminant Production System with Available Resources in the Tropic. Penambul book. Armidale

Rachmawati, N. Suranto dan Solichatun. 2006. Pengaruh variasi metode pengeringan terhadap kadar saponin, angka lempeng total (alt), dan bakteri patogen ekstrak simplisia daun turi (Sesbania grandiflora. J. Biofarmasi 4 (1): 4-9.

Suharti, S., D. A. Astuti dan E. Wina. 2009. Kecernaan nutrient dan performa produksi sapi potong Peranakan Ongole (PO) yang diberi tepung lerak (Sapindus rarak) dalam ransum. JITV 14 (1): 200207.
Suparman, H. Hafid, dan L. Ode, B. 2016. Kajian pertumbuhan dan produktivitas kambing peranakan ettawa jantan yang diberi pakan berbeda. JITRO 3 (3) : 1-9.

Teixeira, E., M. Carvalho, V. Neves, M. Silva, dan P. Arantes. 2014. Chemical characteristics and fractionation of proteins from Moringa oleifera Lam. leaves. J Food Chem 147 ( 2) : 51-54.

Wina, E. 2012. Saponins: Effects on Rumen microbial ecosystem and metabolism in the rumen. In: Patra AK, editor. Dietsary phytochemicals and microbes. London (UK): Springer: 311-350.

Yanti, E. G., Isroli dan T. H. Suprayogi. 2013. Performans darah kambing Peranakan Ettawa dara yang diberi ransum dengan tambahan urea yang berbeda. Animal Agricultural Journal. 2 (1): 439 - 444.

Yatno, Y. 2011. Fraksinasi dan sifat fisik-kimia bungkil inti sawit. Agrinak 01 (1) :11-16. 